Nutrition and Brain 

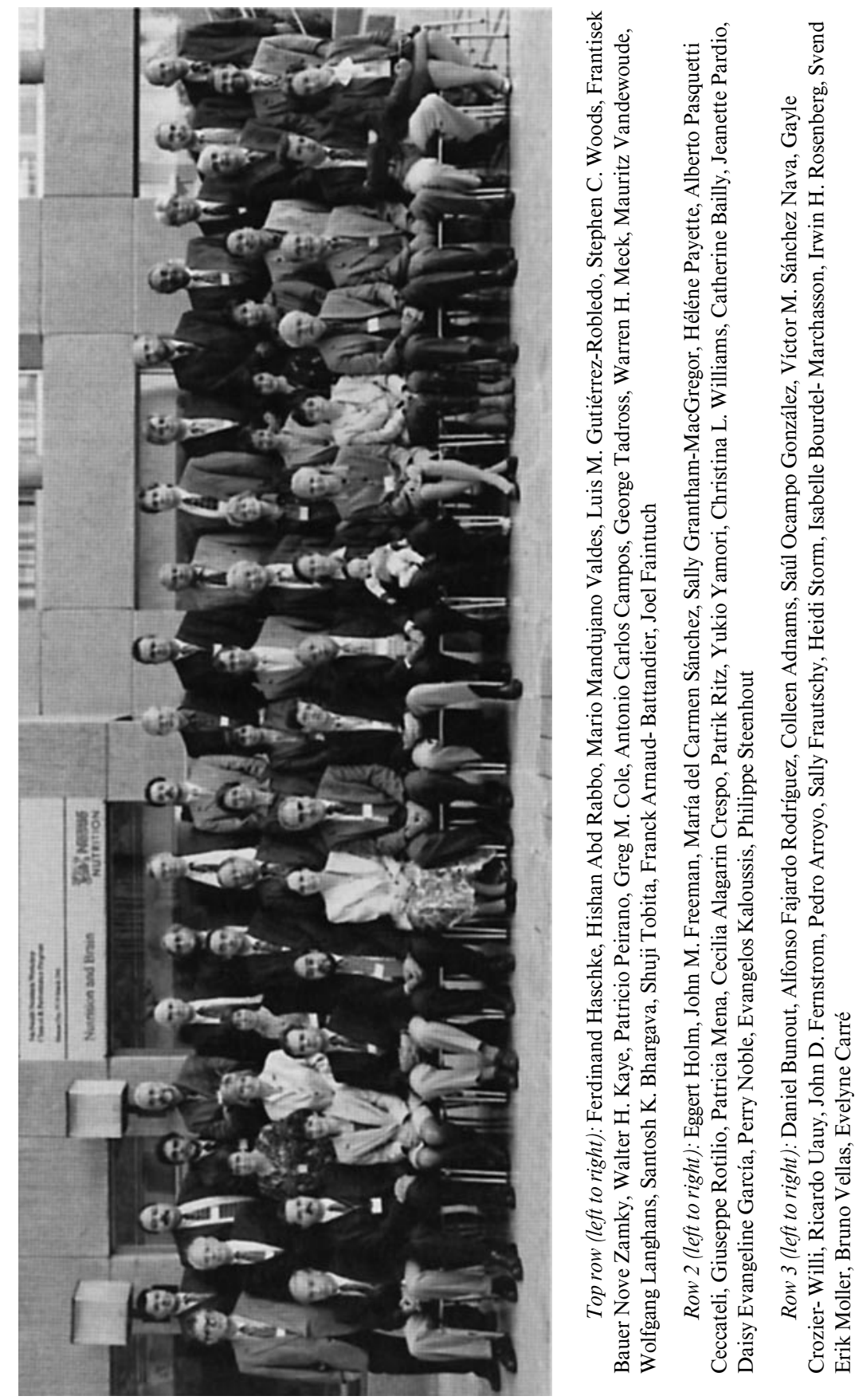
Nestlé Nutrition Workshop Series

Clinical \& Performance Program, Vol. 5

\section{Nutrition and Brain}

John D. Fernstrom, Pittsburgh, Pa., USA

Ricardo Uauy, Santiago, Chile

Pedro Arroyo, Mexico D.F., Mexico 


\section{Nestec Ltd., 55 Avenue Nestlé, CH-1800 Vevey (Switzerland) S. Karger AG, P.O. Box, CH-4009 Basel (Switzerland) www.karger.com}

(c) 2001 Nestec Ltd., Vevey (Switzerland) and S. Karger AG, Basel (Switzerland). All rights reserved. This book is protected by copyright. No part of it may be reproduced, stored in a retrieval system, or transmitted, in any form or by any means, electronic, mechanical, photocopying, or recording, or otherwise, without the written permission of the publisher.

Printed in Switzerland on acid-free paper by Reinhardt Druck, Basel

ISBN 3-8055-7166-6

ISSN $1422-7584$

\section{Library of Congress Cataloging-in-Publication Data}

Nutrition and brain/John D. Fernstrom, Ricardo Uauy, Pedro Arroyo [editors].

p. cm. - (Nestlé Nutrition workshop series. Clinical \& performance program; vol. 5)

Proceedings of a Nestlé Nurition Workshop.

Includes bibliographical references and index.

ISBN 3805571666

1. Brain - Congresses. 2. Nutrition - Congresses. 3. Nutritionally induced diseases - Congresses. 4. Mental illness - Nutritional aspects - Congresses. I. Fernstrom, John D. II. Uauy, Ricardo. III. Arroyo, Pedro. IV. Nestlé Nutrition workshop series. Clinical \& performance program; v. 5.

QP376.N862 2000

612.8 '2 - dc21

00-050645

The material contained in this volume was submitted as previously unpublished material, except in the instances in which credit has been given to the source from which some of the illustrative material was derived.

Great care has been taken to maintain the accuracy of the information contained in the volume. However, neither Nestec Ltd. nor S. Karger AG can be held responsible for errors or for any consequences arising from the use of the information contained herein. 


\section{Contents}

\section{Preface}

XI Foreword

XIII Contributors

1 Undernutrition and Mental Development

S.M. Grantham-McGregor, C.C. Ani (London)

19 Interaction of Iron Deficiency Anemia and Neurofunctions in Cognitive Development

P. Peirano, C. Algarín, M. Garrido, F. Pizarro (Santiago), M. Roncagliolo (Santiago/Valparaiso), B. Lozoff (Ann Arbor, Mich.)

41 Mechanisms for Nutrient Effects on Brain Development and Cognition

R. Uauy (Santiago/Dallas, Tex.), P. Mena, P. Peirano (Santiago)

73 Carbohydrate and Fat-Based Appetite Control Mechanisms W. Langhans (Zürich)

93 Neuropeptides and the Control of Energy Homeostasis

S.C. Woods, P.A. Rushing, R.J. Seeley (Cincinnati, Ohio)

117 Diet, Monoamine Neurotransmitters and Appetite Control

J.D. Fernstrom, M.H. Fernstrom (Pittsburgh, Pa.)

135 Nutrients and Affective Disorders

S.E. Møller (Valby-Copenhagen) 
153 Nutrition, Serotonin and Behavior in Anorexia and Bulimia nervosa

W. Kaye (Pittsburgh, Pa.), K. Gendall (Christchurch), M. Strober (Los Angeles, Calif.)

169 Lipids in Neural Function: Modulation of Behavior by Oral Administration of Endocannabinoids Found in Foods

G. Crozier Willi, A. Berger (Lausanne), V. Di Marzo, T. Bisogno, L. De

Petrocellis (Naples), E. Fride, R. Mechoulam (Jerusalem)

189 Nutritional Impact on Sleep-Wake Cycle

F. García-García, R. Drucker-Colín (Mexico D.F.)

201 Aging, B Vitamins and Cognitive Decline

I.H. Rosenberg (Boston, Mass.)

219 Diet-Related Prevention of Alzheimer's Disease: Different Hypotheses

A.-S. Nicolas, B. Vellas (Toulouse)

231 Nutritional Pathogenesis and Prevention of Stroke

Y. Yamori, K. Ikeda, (Kyoto), M. Tagami, (Kyoto/Tokyo), K. Yamagata and

Y. Nara (Kyoto/Shimonoseki)

247 Risk from Exposure to Metals: Deficits and Excesses (Cu, Fe, Mn, Al, Cr, B)

G. Rotilio (Rome)

263 Nutritional Reversion of Cognitive Impairment in the Elderly D. Bunout, C. Fjeld (Santiago)

283 Metabolic Encephalopathies: Liver Disease, Renal Failure, Critical Illness

E. Holm, R. Breitkreutz, M. Tokus (Heidelberg)

307 The Ketogenic Diet and Epilepsy

J.M. Freeman (Baltimore, Md.)

\section{Subject Index}

Note: Omega-3, $\omega-3$ and n-3 have the same meaning; however, for convenience, n-3 has been used throughout this publication. 


\section{Preface}

The connection between nutrition and brain function has been recognized for almost 100 years. Early investigations focused on nutritional deficiency diseases, such as pellagra and protein-calorie malnutrition, because they were observed to diminish cognition and mental function. Toward the end of the last century, in part because of advances in the ability to study chemical, structural and functional mechanisms underlying brain function, an explosion of interest in the 'blood-brain barrier' as a modulator of nutrient flux into and out of the brain, and the observation that important brain molecules (e.g., neurotransmitters) are readily influenced by changes in the diet, the examination of the interaction between nutrition and brain function expanded phenomenally. This development has led not only to a large body of knowledge regarding how particular nutrients modify brain chemistry and function (e.g., amino acids that are the precursors of brain neurotransmitters; essential fatty acids that are the precursors of important structural lipids and signaling molecules in brain, vitamins that are cofactors in key metabolic pathways in brain), how nutrients alter the secretion of hormones that directly influence brain function, and how diet, by modifying aspects of body metabolism, alters brain function (e.g., in starvation via changes in important metabolic intermediates). It has also precipitated a growing recognition that the brain may not be a passive recipient of such changes, but may perceive them as signals to institute nutritional and metabolic adjustments (e.g., to modify food selection). During the past decade, advances in the nutrition-brain area have also led to the concept that nutrients and diet may be useful in treating or preventing disease states not previously identified with food intake, such as epilepsy, certain metabolically-derived encephalopathies, and the loss of cognitive function and memory that accompanies aging. 
The recognition that advances in the nutrition-brain interaction area are leading to new insights in the treatment and prevention of disease stimulated the choice of the nutrition-brain topic for the 5th Nestlé Nutrition Workshop. The workshop Nutrition and the Brain attempted to highlight the diversity in this area of investigation, rather than focus on a specific topic, in order to cross-foster ideas and stimulate discussion, and to promote new insights into the study of this complex topic. The proceedings volume reflects this diversity. The first section focuses on that aspect of nutrition and brain function relating to nutritional inadequacies; it documents the role nutritional inadequacies can play in limiting cognitive development and mental function in underdeveloped countries, and discusses some of the changing demographics in these countries that may contribute to, exacerbate or change the etiology of undernutrition. The second section considers some of the more basic aspects of the nutrition-brain link by reviewing experimental evidence illuminating mechanisms currently thought to govern energy homeostasis in the body, appetite and food choice. It discusses the roles of several neurotransmitters and hormones in this process, their relation to diet, and considers the possibility that their actions can lead to new pharmacologic strategies for controlling appetite and energy balance, an issue of particular relevance in countries where obesity is now a public health crisis. The third section focuses on specific issues relating nutrition to brain function in humans. Here, food intake is linked to sleep, mood and food intake. In particular, the connection between the intake of tryptophan and other amino acids is examined in relation to depression. And, the eating disorders (bulimia nervosa, anorexia nervosa) are discussed from the perspective that inherited abnormalities in the functioning of neurotransmitters (notably serotonin) derived from amino acids may promote very unusual dietary practices in patients in an attempt to moderate these transmitter aberrations. Foods are also considered as matrices for naturally-occurring, brain-active agents having notable, pharmacologic, receptor-mediated actions on brain function. The fourth section considers nutritional factors that may contribute to the loss of cognitive functioning with aging. Specific topics discussed include the possibilities that inadequate vitamin B status in aging can compromise cognitive function by changing important methylation reactions in brain, and/or possibly by increasing the risk of occlusive vascular disease and stroke; that cognitive deficits, such as those that develop in patients with Alzheimer's disease, may result from oxidative damage, and thus be treated or prevented through the use of dietary antioxidants (e.g., vitamin E); that neurodegeneration can result from deficits or excesses in the intake of metals like copper, iron, chromium and aluminum that can promote oxidative injury to neurons and glia in brain, and that inherited susceptibilities to stroke may be caused by particular nutritional excesses and inadequacies. The fifth section presents examples of disease states that affect mental function, and how diet can be used to ameliorate disease symptomatology. Liver and renal disease offer 
insight into dietary manipulations that moderate the metabolic aberrations occurring outside the brain to improve mental function, while epilepsy offers the remarkable example of a dietary strategy that appears to control seizure activity in the brains of children for whom no other treatment has succeeded.

Overall, this workshop provided a forum for highlighting many of the diverse areas of investigation linking nutrition and metabolism to the normal (and abnormal) functioning of the brain. It served to facilitate links between several of these disciplines, and hopefully will stimulate new insights and research. Our expectation is that it will also ultimately lead to new clinical applications in this area, and serve to improve patient care. We hope that this publication will serve to inform, update and stimulate clinicians and scientists interested in nutrition-brain interactions.

John D. Fernstrom, Ricardo Uauy 


\section{Foreword}

Undernutrition early in life results in impaired growth but also in lower IQ, cognitive deficits, behavioral problems, and impaired motor skills. It has been proven that deficits continue until school age, adolescence, and even adulthood. Prevention through healthcare measures and an improved socioeconomic environment are of paramount importance in worldwide efforts. It is amazing that adequate nutritional supplements provided during the third trimester of pregnancy and during the first 2 years of life can protect the brain but supplementation later on in life has little effect. Future research focusing on the nutrient-gene interactions in the case of early malnutrition will contribute to the creation of more targeted programs to protect the brain.

Mood disorders in adults have a prevalence of $11 \%$ and result in significant disability. The death rate from anorexia nervosa is above 10\%. Underdiagnosis and undertreatment of those disorders is common. Nutrient effects on mood, behavior, and psychiatric disorders can be used to prevent disease or even support treatment. The research in the field of aromatic amino acids and long-chain polyunsaturated fatty acids is most encouraging.

Vascular disease is a risk factor for inadequate blood supply of the aging brain. Increased plasma homocysteine as a marker for low $\mathrm{B}_{12}$, folate, and $\mathrm{B}_{6}$ status has been identified as an indicator for vascular disease. Adequate supply of those vitamins and antioxidants could play an important role in the prevention of stroke and Alzheimer's disease. In addition, the reversal of age-related impairment in cognitive function by dietary manipulation must be a long-term goal for nutritional intervention. 
Foreword

I would like to take this opportunity to thank the Chairmen, Professor John Fernstrom and Doctors Ricardo Uauy and Pedro Arroyo for their contribution to this workshop. Our thanks to the Nestlé team who organized the workshop, in particular to Mr. Zurita in Mexico and Dr. Philippe Steenhout at the Center, who helped to set up this workshop.

Prof. Ferdinand Haschke, MD

Vice-President

Nestec Ltd, Vevey, Switzerland 


\section{Contributors}

\section{Speakers}

\section{Dr. Pedro Arroyo}

Fundación Mexicana para la Salud Periférico Sur 4809

El Arenal Tepepan - Tlalpan

14610 Mexico, D.F.

Mexico

Tel. +52 56559011 or 6553402

$F a x+5256558211$

E-mail:

parroyo@lucas.funsalud.org.mx

\section{Dr. Daniel Bunout}

Instituto de Nutrición y Tecnologia de los Alimentos (INTA)

Av. Macul 5540

Santiago

Chile

E-mail:dbunout@uec.inta.uchile.cl

\section{Dr. Gayle Crozier-Willi}

Nestec Ltd

Av. Nestlé 55

CH-1800 Vevey

Switzerland

Tel. +41219243273
$F a x+41219244547$

E-mail:

gayle.crozier-willi@nestle.com

\section{Dr. René Drucker-Colin}

Depto.de Fisiologia Facultad de Medicina

Universidad Nacional Autonoma de Mexico (UNAM)

Apdo. Postal 70-250

Mexico D.F.

Mexico

Tel. +52 55502920

Fax +52 56232241

E-mail:drucker@servidor.unam.mx

\section{Prof. John D. Fernstrom}

University of Pittsburgh School of Medicine

Room 1620

3811 O'hara Street

Pittsburgh, PA 15213, USA

Tel. +14126242032

$F a x+14126243696$

E-mail:fernstromjd@msx.upmc.edu 


\section{Dr. John M. Freeman}

Johns Hopkins Hospital The Pediatric Epilepsy Center 600 N. Wolfe Street/ Meyer 2-147 Baltimore, MD 21287-7247, USA

Tel. +14109559100 $\mathrm{Fax}+14106140373$ E-mail:jfreema@jhmi.edu

\section{Dr. Sally Grantham-MacGregor}

Centre for International Child Health Institute of Child Health 30 Guilford Street WC1N 1EH London, UK Tel. +44207242 9789 ext. 2160 Fax +442074042062 E-mail:S.McGregor@ich.ucl.ac.uk

\section{Prof. Eggert Holm}

Department of Pathophysiology Medical Clinic I, University of Heidelberg

Theodor Kutzer Ufer

D-68167 Mannheim

Germany

Tel. +496213832643

Fax +496213832191

E-mail:eggert.holm@med1.ma.uniheidelberg.de

\section{Dr. Walter H. Kaye}

Western Psychiatric Institute and Clinic

3811 O'Hara Street, Room E-724

Pittsburgh, PA 15213-2593, USA

Tel. +14126243507

$\mathrm{Fax}+14126246811$

E-mail:kayewh@msx.upmc.edu

\section{Prof. Wolfgang Langhans}

Physiology \& Animal Husbandry Institute of Animal Sciences Swiss Federal Institute of Technology (ETH)

Universitätstrasse 2

CH-8092 Zurich

Switzerland

Tel. +4101632 3306
Fax +41016321308

E-mail:

wolfgang.langhans@inw.agrl.ethz.ch

\section{Dr. Svend Erik Møller}

International Marketing

H. Lundbeck $A / S$

Ottiliavej 9

DK-2500 Valby-Copenhagen

Denmark

Tel. +453630 1311 ext. 2822

$F a x+4536440455$

E-mail:sem@lundbeck.com

\section{Dr. Patricio Peirano}

Instituto de Nutrición y Tecnologia de los Alimentos (INTA)

Av. Macul 5540

Santiago, Chile

E-mail:ppeirano@uec.inta.uchile.cl

\section{Prof. Irwin H. Rosenberg}

Jean Mayer HNRC

Tufts University

711 Washington Street

Boston, MA 02111, USA

Tel. +16175563254

$F a x+16175563295$

E-mail: rosenberg@HNRC.Tufts.Edu

\section{Prof. Giuseppe Rotilio}

Istituto Nazionale della Nutrizione

Via Ardeatina 546

I-00178 Rome, Italy

Tel. +390672594373

Fax +390672504311

E-mail:president@inn.ingrm.it

rotilio@bio.uniroma2.it

\section{Dr. Ricardo Uauy}

Instituto de Nutrición y Tecnologia de los Alimentos (INTA)

Av. Macul 5540

Santiago, Chile

Tel. +56 2 2214105

$F a x+5622214030$

E-mail:uauy@abello.dic.uchile.cl 


\section{Prof. Bruno Vellas}

CHU Casselardit

Service de Médecine Interne et

Gérontologie Clinique

170 avenue de Casselardit

F-31300 Toulouse

France

Tel. +33 561777649

Fax +33561497109

E-mail:vellas.b.@chu.toulouse.fror

Bvellas@aol.com

\section{Prof. Steve C. Woods}

Obesity Research Center

University of Cincinnati

Medical College

PO Box 670559

\section{Participants}

\section{Belgium}

Prof. Mauritz Vandewoude

\section{Brazil \\ Dr. Antonio Carlos Campos \\ Dr. Joel Faintuch}

\section{Canada}

Dr. Hélène Payette

\section{Chile}

Dr. Patricia Mena

\section{Egypt}

Dr. H. Abd Rabbo

\section{France}

Dr. Isabelle Bourdel-Marchasson

Dr. Evelyne Carré

Prof. Patrick Ritz

\section{India}

Dr. Santosh Bhargava
Cincinnati, OH 45267-0559, USA

Tel. +15135586799

Fax +15135588990

E-mail:

steve.woods@psychiatry.uc.edu

\section{Prof. Yukio Yamori}

Graduate School of Human and Environmental Studies

Kyoto University

Yoshida Nihonmatsu-cho, Sakyo-ku

Kyoto, 606-8501, Japan

Tel. +810757536880

$\mathrm{Fax}+810757532997$

E-mail:

yamori@helios.jinkan.kyoto-u.ac.jp

\section{Japan}

Dr. Shuji Tobita

\section{Mexico}

Dr. Alfonso Fajardo Rodrıguez

Dr. Saúl Garza

Morales

Dr. Luis M. Gutiérrez Robledo

Dr. Mario Mandujano Valdés

Dr. Saúl Ocampo González

L.N. Jeanette Pardio López

Dr. Alberto Pasquetti Ceccateli

Dra. Sandra Porcayo Liborio

Dr. Francisco Revilla Pacheco

Dr. Abelardo Salazar Zuñiga

Dra. María del Carmen Sánchez

Dr. Victor M. Sánchez Nava

Dr. Jesús Tapia Jurado

\section{Philippines}

Dr. Perry Noble

Dr. Daisy Evangelinne Garcia 


\section{Slovakia}

Dr. Franstisek Bauer

South Africa

Dr. Coleen Adnams

\section{United States of America}

Dr. Gregory Cole

Prof. Sally A. Frautschy

Prof. Warren H. Meck

Dr. Christina L. Williams

\section{Nestlé attendees}

Jorge Arévalo / Mexico

Franck Arnaud-Battandier, MD / France

Catherine Bailly / Switzerland

Ferdinand Haschke, PHD, MD / Switzerland

Fernando Infante Pizano / Mexico

Evangelos Kaloussis / Switzerland

Philippe Steenhout, MD / Switzerland

Heidi Storm / USA

George Tadross / Egypt 